\title{
GENETIC VARIABILITY, SHELL AND SPERM MORPHOLOGY SUGGEST THAT THE SURF GLAMS DONAX MARINGOVICHI AND D. OBESULUS ARE ONE SPEGIES
}

\author{
DANIEL GARSTENSEN ${ }^{1}$, JÜRGEN LAUDIEN ${ }^{1}$, FLORIAN LEESE ${ }^{1,2}$, \\ WOLF ARNTZ ${ }^{1}$ AND CHRISTOPH HELD ${ }^{1}$ \\ ${ }^{1}$ Alfred Wegener Institute for Polar and Marine Research, PO Box 120161, D-27515 Bremerhaven, Germany; and \\ ${ }^{2}$ Department of Animal Ecology, Evolution and Biodiversity, Ruhr University Bochum, Universitätsstrasse 150, D-44801 Bochum, Germany
}

(Received 22 December 2008; accepted 29 April 2009)

\begin{abstract}
The taxonomy of two sympatric surf clams Donax marincovichi Coan, 1983 and Donax obesulus Reeve, 1854, inhabiting the coastal Humboldt Current Upwelling System is revisited. Because both species are exploited by artisanal fisheries, it is essential to verify that they are indeed distinct species that have to be managed separately. In this study, both taxa were sampled across their shared distributional area and specimens were indentified according to their respective morphological characteristics. Although width/height and height/length ratios revealed significant differences within sampling areas, the two morphotypes were frequently incongruent for taxonomically important morphometric parameters. In addition, they showed no significant mitochondrial genetic differentiation within or among populations and exhibited indistinguishable sperm ultrastructure. We conclude that the two morphotypes do not represent distinct species and should be included together under D. obesulus.
\end{abstract}

\section{INTRODUGTION}

The bivalve genus Donax is distributed almost worldwide, except for polar regions, and can be locally very abundant on exposed sandy beaches (Ansell, 1983). Donacidae occupy a major role in nearshore trophic webs, as they feed on phytoplankton, while in turn they are prey for gastropods, demersal fish, birds and mammals (Ansell, 1983). These bivalves represent an important resource for artisanal fisheries and local markets (Paredes \& Cardoso, 2001; Rey, 2006, 2007, 2008; Riascos, 2006) and are exported, e.g. to Europe. Two species, Donax marincovichi Coan, 1983 and Donax obesulus Reeve, 1854, are distributed along the Humboldt Current Upwelling System from northern Chile to northern Ecuador (Fig. 1, Table 1). Within their shared distributional range both species reveal a broad range of shell shapes (Coan, 1983; Guzmán, Saá \& Ortlieb, 1998).

The taxonomic status of several species of Donacidae has been much debated (Loesch, 1957; Wade, 1967a, b; Chanley, 1969; Morrison, 1971; Narchi, 1983; Bonsdorff \& Nelson, 1992; Nelson, Bonsdorff \& Adamkewicz, 1993; Guzmán et al., 1998; Paredes \& Cardoso, 2001; Laudien, Flint \& van der Bank, 2003). The difficulty of species recognition is demonstrated by the reduction of 'valid' species from 64 (Ansell, 1983) to 45 in a recent taxonomic revision of the genus (Coan, Scott \& Bernard, 2000). Clearly, confusion in taxonomical classification has led to numerous synonyms. The uncertain taxonomic status of the Chilean and Peruvian species D. marincovichi and D. obesulus is reflected in the current taxonomic literature (Olsson, 1961; Keen, 1971; Coan, 1983; Guzmán et al., 1998; Paredes \& Cardoso, 2001). In Chile these clams are informally known as 'machilla' and in Peru as 'mariposa', 'palabrita', 'concha blanca' or 'marucha' (Huaraz \& Ishiyama, 1980; Soto, 1985; Paredes \& Cardoso, 2001; Rey, 2006). Both species are exploited by the artisanal fisheries and are managed as one evolutionarily significant unit referred to as Donax peruvianus (Paredes \& Cardoso, 2001; Rey, 2006, 2007, 2008). However, to verify

Correspondence: D. Carstensen; e-mail: daniel.carstensen@awi.de management strategies and to optimize sustainable exploitation it is essential to know if $D$. marincovichi and D. obesulus can be treated as one species or if they have to be managed separately.

To clarify the taxonomic status of $D$. marincovichi and D. obesulus three different taxonomic methods were applied: (1) shells were classified after Coan (1983), followed by statistical evaluation of two morphometric parameters; (2) morphometric comparison of sperm ultrastructure of both species was performed using transmission electron microscopy (TEM); (3) sequence data of partial cytochrome $c$ oxidase subunit 1 gene (COI) were used to estimate inter- and intraspecific similarities among geographically distant populations along the northern Chilean and Peruvian distributional area.

Sperm ultrastructural studies have provided a useful tool for taxonomic and phylogenetic investigations of bivalves for $>45$ years (Galtsoff \& Gallardo, 1960).

In particular, genetic tools have been shown to be very suitable for resolving taxonomic and systematic problems, and techniques such as DNA barcoding have revealed a great capacity to define species boundaries (Kimura \& Weiss, 1964; Levinton \& Suchanek, 1978; Koehn et al., 1984; Utter, 1991; Held, 2000; Hebert, Ratnasingham \& DeWaard, 2003; Held \& Wägele, 2005; Witt, Threloff \& Hebert, 2006; Coghlan \& Gosling, 2007). Genetic analyses are not only helpful in clarifying phylogenetic relationships, but also provide possibilities to analyse intraspecific relatedness between single populations and hence larval dispersal between regions and the dependence of recruitment on local stocks (Adamkewicz \& Harasewych, 1994; Soares, 1999; Laudien et al., 2003; Coghlan \& Gosling, 2007).

For the clarification of the taxonomic status a combination of both morphological and genetic analyses is particularly effective for species identification (Jaernegren et al., 2007).

\section{MATERIAL AND METHODS}

\section{Material}

Specimens ( $n=109$ : Donax marincovichi $n=56$ and Donax obesulus $n=53$ ) were sampled at 10 locations along their 


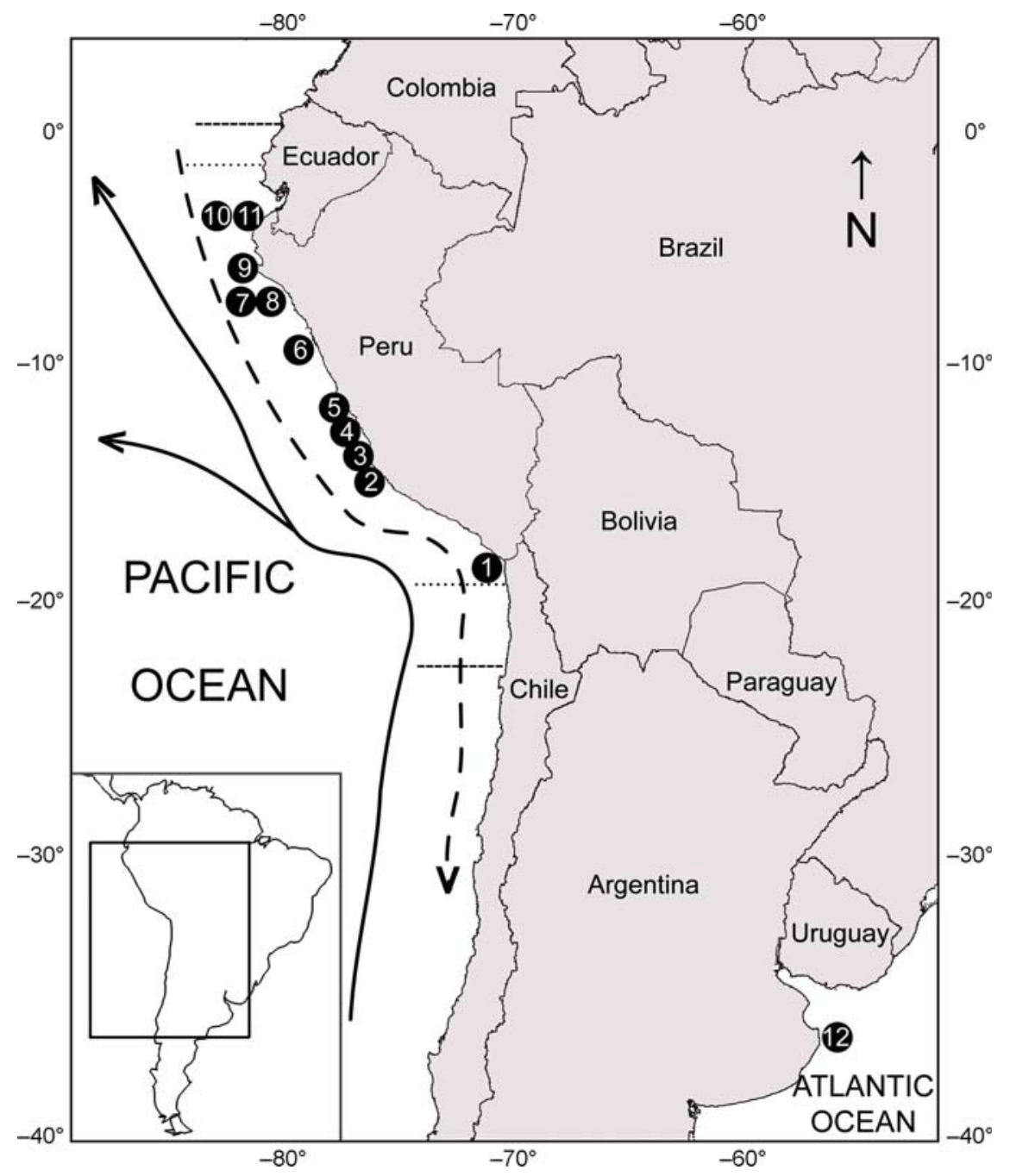

Figure 1. Distribution of Donax marincovichi (dotted line) $\left(18^{\circ} 28^{\prime} \mathrm{S} ; 70^{\circ} 20^{\prime} \mathrm{W} ; 2^{\circ} 12^{\prime} \mathrm{S} ; 80^{\circ} 58^{\prime} \mathrm{W}\right)$ and Donax obesulus (dashed line) $\left(23^{\circ} 28^{\prime} \mathrm{S} ; 70^{\circ} 31^{\prime} \mathrm{W}\right.$; $0^{\circ} 27^{\prime} \mathrm{S} ; 80^{\circ} 7^{\prime} \mathrm{W}$ ) and sampling stations $(1-11)$ along the Chilean and Peruvian coast. Outgroups Donax asper and Donax hanleyanus were sampled at Stations 11 and 12. For further details see Table 1. Peru Coastal Current (solid arrows) and Peru Chile Undercurrent (dashed arrow), simplified after Tarazona \& Arntz (2000).

Table 1. Sampling sites of Donax marincovichi $(n=56)$, Donax obesulus $(n=53)$ and Donax outgroups (Donax asper and Donax hanleyanus).

\begin{tabular}{|c|c|c|c|c|c|c|c|}
\hline Station & Country & City nearby & Beach & Longitude & Latitude & D. marincovichi & D. obesulus \\
\hline 1 & Chile & Arica & Chinchorro & $\mathrm{S} 18^{\circ} 27^{\prime} 53.8^{\prime \prime}$ & W70 $18^{\prime} 24.3^{\prime \prime}$ & & 11 \\
\hline 2 & Peru & Chincha & Violetas & $\mathrm{S} 13^{\circ} 29^{\prime} 05.6^{\prime \prime}$ & W76 $11^{\prime} 25.4^{\prime \prime}$ & 11 & \\
\hline 3 & Peru & San Bartolo & Silencio & $\mathrm{S} 13^{\circ} 24^{\prime} 33.0^{\prime \prime}$ & W76 $11^{\prime} 49.1^{\prime \prime}$ & 11 & \\
\hline 4 & Peru & Bujama & Sarapampa & $S 12^{\circ} 43^{\prime} 20.4^{\prime \prime}$ & W76 $37^{\prime} 42.4^{\prime \prime}$ & 10 & 1 \\
\hline 5 & Peru & Asia & Asia & $\mathrm{S} 12^{\circ} 48^{\prime} 04.0^{\prime \prime}$ & W76 $33^{\prime} 56.4^{\prime \prime}$ & 10 & 1 \\
\hline 6 & Peru & Chimbote & El Dorado & S09 $10^{\prime} 24.5^{\prime \prime}$ & W78 $32^{\prime} 12.6^{\prime \prime}$ & 8 & 2 \\
\hline 7 & Peru & Chiclayo & La Laguna & $\mathrm{S} 07^{\circ} 04^{\prime} 08.7^{\prime \prime}$ & W79 $44^{\prime} 00.2^{\prime \prime}$ & & 11 \\
\hline 8 & Peru & Chiclayo & La Laguna & $\mathrm{S} 07^{\circ} 04^{\prime} 23.5^{\prime \prime}$ & W79 $43^{\prime} 47.1^{\prime \prime}$ & 6 & 5 \\
\hline 9 & Peru & Sechura & San Pedro & $\mathrm{S} 05^{\circ} 29^{\prime} 49.8^{\prime \prime}$ & W80 $53^{\prime} 53.7^{\prime \prime}$ & & 11 \\
\hline 10 & Peru & Tumbes & Hueso de Ballena & $\mathrm{S} 03^{\circ} 30^{\prime} 20.5^{\prime \prime}$ & W80 $29^{\prime} 04.0^{\prime \prime}$ & & 11 \\
\hline 11 & Peru & Tumbes & Hueso de Ballena & $\mathrm{S} 03^{\circ} 30^{\prime} 20.5^{\prime \prime}$ & W80 $29^{\prime} 04.0^{\prime \prime}$ & Donax asper & \\
\hline 12 & Argentina & Villa Gesell & Mar Azul & $\mathrm{S} 37^{\circ} 20^{\prime} 44.8^{\prime \prime}$ & W5 $57^{\circ} 01^{\prime} 41.3^{\prime \prime}$ & Donax hanleyanus & \\
\hline
\end{tabular}

The numbers of the respective morphotypes indentified for each station are listed in the last two columns.

distributional range (Fig. 1, Table 1, Stations 1-10). Specimens of Donax asper from northern Peru (Tumbes; Fig. 1, Table 1, Station 11) and Donax hanleyanus from the Atlantic coast of Argentina (Villa Gesell; Fig. 1, Table 1,
Station 12) were sampled as outgroups within the Donacidae. To avoid ontogenetic differences in shell morphology adult specimens (min, $15.02 \mathrm{~mm}$; $\max , 29.97 \mathrm{~mm}$ ) were chosen for analysis. 
Table 2. Differentiation of Donax marincovichi and D. obesulus after Coan (1983).

\begin{tabular}{lll}
\hline & Donax marincovichi & Donax obesulus \\
\hline 1. Fig. 2A-D & Never has punctations & Punctations present on most specimens \\
2. Fig. 2E/F & Less inflated, W/H $0.57-0.69$ & More inflated, W/H $0.71-0.77$ \\
3. Fig. 2E/F & Beaks low & Beaks inflated \\
4. Fig. $2 \mathrm{G} / \mathrm{H}$ & Periostracum dark & Periostracum light \\
5. Fig. $2 \mathrm{G} / \mathrm{H}$ & Periostracum adherent in a wide marginal band & Periostracum light, marginal traces only \\
6. Fig. $2 \mathrm{~A}-\mathrm{D}$ & Surface silky & Surface shiny \\
7. Fig. $2 \mathrm{I} / \mathrm{J}$ & Posterior lateral more distant from cardinals & Posterior lateral close to cardinals \\
8. Fig. $2 \mathrm{~K} / \mathrm{L}$ & Dorsal margin not produced above posterior lateral & Dorsal margin produced above posterior lateral \\
9. Fig. $2 \mathrm{I}-\mathrm{L}$ & Anterior cardinal of right valve small, thin & Anterior cardinal of right valve thickened \\
10. Not considered & Maximum size $32 \mathrm{~mm}$ & Maximum size 38 mm \\
\hline
\end{tabular}

\section{Shell morphology}

Based on shell characteristics (following Coan, 1983) all individuals were identified as $D$. marincovichi or $D$. obesulus (Table 2). Specimens were measured with a vernier calliper $( \pm 0.01 \mathrm{~mm}$ ) to record length (anterior-posterior, L), height (ventro-dorsal, $\mathrm{H}$ ) and width (left-right, W). Width/height $(\mathrm{W} / \mathrm{H})$ and height/length $(\mathrm{H} / \mathrm{L})$ ratios were calculated and the nonparametric Kruskal-Wallis test was used to evaluate statistical differences of each ratio among all stations. When the Kruskal-Wallis test revealed significant differences, post hoc comparisons were performed using the Dunn test at a level of $5 \%$ significance to evaluate paired (i.e. between every pair) differences (Zar, 1999). The character of 'maximum anteriorposterior shell length' specified by Coan (1983) for D. marincovichi $(32 \mathrm{~mm})$ and D. obesulus $(38 \mathrm{~mm})$ was not applied in this study as all specimens lay below these values (D. marincovichi, $29.75 \mathrm{~mm}$; D. obesulus, $27.83 \mathrm{~mm}$ maximum lengths).

\section{Sperm morphology}

In order to compare sperm morphology, gonads of $D$. marincovichi and $D$. obesulus were dissected, $c .1 \mathrm{~mm}^{3}$ of tissue (always from the same area) was fixed in $4 \%$ glutaraldehyde buffered with $0.1 \mathrm{M}$ disodium phosphate buffer $(\mathrm{pH} 7.4)$ for $4 \mathrm{~h}$ at $4^{\circ} \mathrm{C}$ and then thoroughly rinsed in phosphate buffer. Tissue samples were dehydrated using an ascending series of ethanol (from $20 \%$ to absolute ethanol) and embedded in Araldite resin. Ultra-thin sections were produced using an LKB 2128 ultramicrotome after mounting the tissue on $200-\mu \mathrm{m}$ mesh uncoated copper grids, stained with uranyl acetate $(10-20 \mathrm{~min})$ and lead citrate $(10-20 \mathrm{~min})$. For further details of preparation see Giménez et al. (2008). Ultrastructural sperm morphology was photographed with a TEM Philips EM 301 at $60 \mathrm{kV}$ and a Jeol 1200 EX II at $80 \mathrm{kV}$. All measurements on sperm structures are based on TEM observations. As there are several important changes during maturation of sperm, such as changes in the acrosome and the positioning of the mitochondria (Pal, 1996), only mature sperm were analysed. Characterization of sperm morphology was realized by a precise identification of the general components of sperm (acrosome, nucleus, midpiece and flagellum).

\section{Genetic analyses}

For a subset of 79 Donax specimens (D. asper, $n=9$; D. hanleyanus, $n=9$; D. marincovichi, $n=25$ and D. obesulus, $n=36$ ) we sequenced a fragment of the mitochondrial COI gene. Individuals with opened and closed shells were preserved from each beach in $>80 \%$ ethanol. Muscle tissue was extracted from the middle and apex region $\left(c .1 \mathrm{~mm}^{2}\right)$ of the foot and cleaned with ethanol $(75 \%)$ to remove sand, detritus or external organic matter. The muscle tissue was cut into small pieces to decrease tissue lysis time. To avoid contamination of DNA, extraction was carried out under sterile conditions. DNA extraction was performed with the Qiagen DNA Mini kit using the standard tissue protocol. However, in a modification of this protocol, only $150 \mu \mathrm{l}$ of elution buffer was used to increase the concentration of DNA.

Initially, DNA amplification of two mitochondrial genes (COI, 16S) was attempted using universal primers (Palumbi, Martin \& Romano, 1991; Folmer et al., 1994). The ribosomal large subunit gene (16S) did not amplify in many specimens and, therefore, further analyses focused on the COI gene, which amplified successfully using the primers LCO-1490 and HCO-2198 (Folmer et al., 1994).

Amplification of the COI fragment was carried out in $25 \mu \mathrm{l}$ reactions containing $1 \times$ HotMaster buffer, $0.2 \mathrm{mM}$ dNTPs, $0.5 \mu \mathrm{M}$ of each primer, $1-3 \mu \mathrm{l}$ of DNA template, $0.02 \mathrm{U} / \mu \mathrm{l}$ HotMaster Taq polymerase (5 prime, Hamburg, Germany), filled up to $25 \mu \mathrm{l}$ with sterile $\mathrm{H}_{2} \mathrm{O}$. The PCR temperature profile for the COI amplification was: $94^{\circ} \mathrm{C}$ for $2 \mathrm{~min}, 38$ cycles of $20 \mathrm{~s}$ at $94^{\circ} \mathrm{C}, 15 \mathrm{~s}$ at $42^{\circ} \mathrm{C}, 80 \mathrm{~s}$ at $65^{\circ} \mathrm{C}$, followed by a final extension step of $7 \mathrm{~min}$ at $65^{\circ} \mathrm{C}$.

PCR products were checked on a $1.5 \%$ TAE agarose gel and purified using a Qiagen QIAquick PCR purification kit according to the manufacturers' recommendations. Cycle-sequencing of PCR products was carried out using terminal primers given above and the BigDye Terminator v3.1 kit of Applied Biosystems (ABI), purified using DyeEx-Kit (Qiagen) according to the modified protocol and sequenced on an ABI 3130xl automated sequencer.

Sequences were aligned using MUSCLE (Edgar, 2004). As outgroup for the alignment, a sequence of Macoma balthica was used (GenBank accession number EF044136). Phylogenetic analyses were performed using MrBayes 3.1.2 (Huelsenbeck \& Ronquist, 2001). The optimal model of sequence evolution was identified using hierarchical likelihood ratio tests and the Akaike Information Criterion (AIC) as implemented in MrModeltest 2.2 (Nylander, 2004). The MCMC analyses was performed using two independent runs with 10 million generations each and sampling every 100th tree. Convergence was reached after 60.000 generations (discarded as burn-in). A statistical parsimony network was calculated from the D. marincovichi and D. obesulus data set using TCS 1.21 (Clement et al., 2000) and a 95\% connection limit.

\section{RESULTS}

\section{Shell morphology}

Based on Coan's (1983) morphological characters, specimens $(n=109)$ from 10 different locations from northern Chile to 


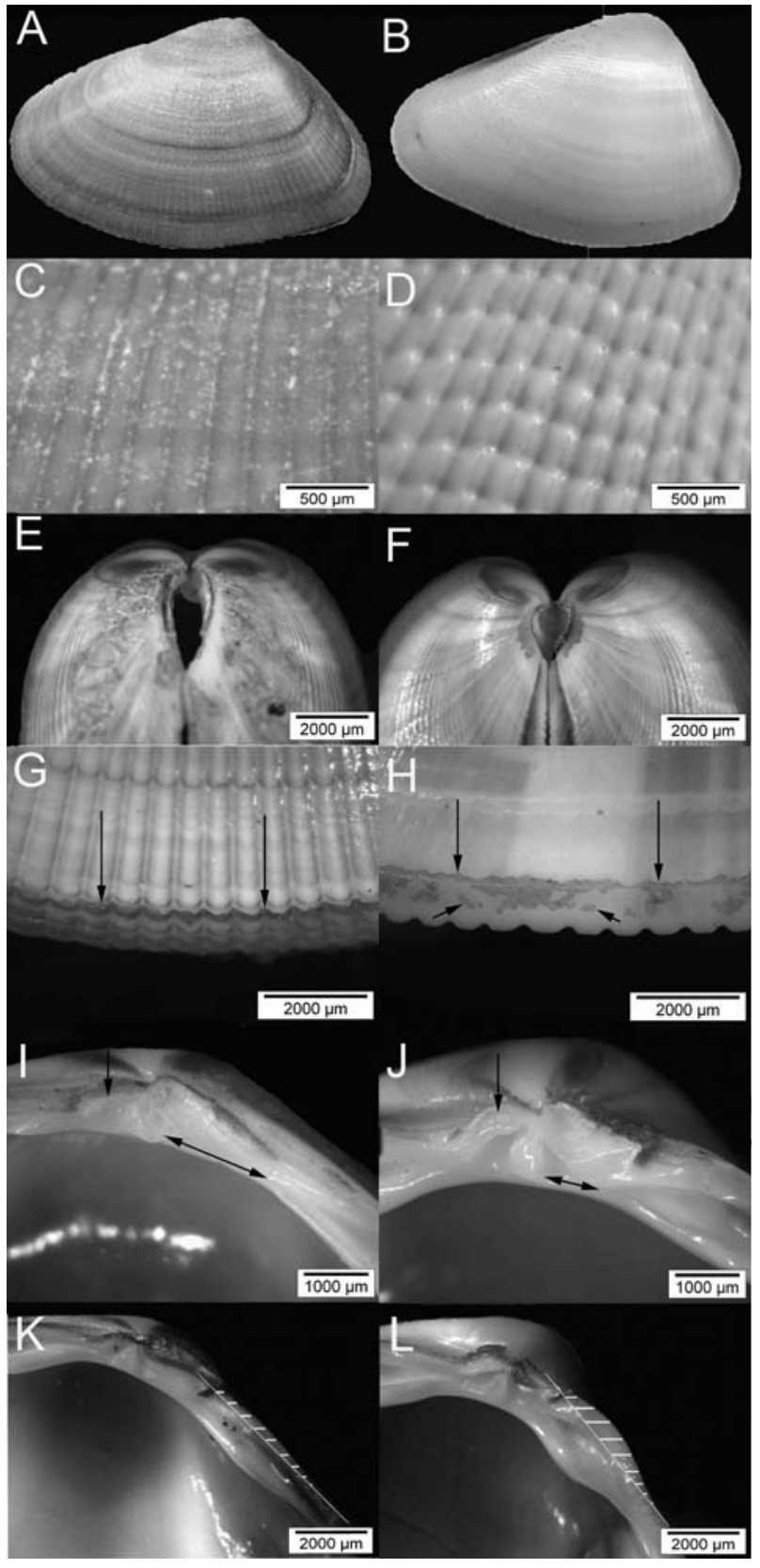

Figure 2. A. Donax marincovichi (left valve, $23 \mathrm{~mm}$ ). Valve is less inflated, $\mathrm{W} / \mathrm{H}$ between 0.57 and 0.69 , maximum length $32 \mathrm{~mm}$. B. Donax obesulus (left valve, $17 \mathrm{~mm}$ ), valve is more inflated, W/H between 0.71 and 0.77. G. Donax marincovichi never has punctation, surface silky $(32 \times)$. D. Donax obesulus shows punctation on most specimens, surface shiny $(32 \times)$. E. Donax marincovichi: posterior dorsal half, beaks low $(10 \times)$. F. Donax obesulus: posterior dorsal half, beaks inflated $(10 \times)$. G. Donax marincovichi: left valve ventral margin: periostracum dark, adherent, in a wide marginal band $(10 \times)$. H. Donax obesulus: left valve ventral margin: periostracum light, marginal traces only $(10 \times)$. I. Donax marincovichi: right valve hinge region close to umbo: posterior lateral more distant (double-headed arrow) and anterior cardinal of right valve (single-headed arrow) small, thin $(12.5 \times)$. J. Donax obesulus: right valve hinge region close to umbo: posterior lateral close to cardinals (double-headed arrow) and anterior cardinal (single-headed arrow) of right valve thickened $(12.5 \times)$. K. Donax marincovichi: dorsal margin less (or not) produced above posterior lateral (hatched area) $(7 \times)$. L. Donax obesulus: dorsal margin produced above posterior lateral (hatched area) $(7 \times)$.
Table 3. Number of mismatches (inapplicable identification feature, as number and as percentage) for Donax marincovichi and Donax obesulus for each character (Fig. 2, Table 2).

\begin{tabular}{lcrlr}
\hline & $\begin{array}{l}\text { Donax marincovichi } \\
(n=56)\end{array}$ & $\%$ & $\begin{array}{l}\text { Donax obesulus } \\
(n=53)\end{array}$ & $\%$ \\
\hline 1. Punctation & 0 & 0 & 0 & 0 \\
2. W/H & 8 & 14 & 5 & 9 \\
3. Beak & 1 & 2 & 7 & 13 \\
4. Periostracum & 50 & 88 & 2 & 4 \\
$\quad$ colour & & & & \\
5. Periostracum & 20 & 35 & 13 & 25 \\
$\quad$ marginal & & 16 & 1 & 2 \\
6. Surface & 9 & 65 & 5 & 12 \\
7. Posterior lateral & 37 & 0 & 13 & \\
8. Dorsal margin & 0 & 19 & 13 & \\
9. Anterior cardinal & 11 & & 58 & \\
Total & 133 & &
\end{tabular}

Maximal size (character 10, Table 2) was not considered as there were no specimens available reaching the maximum size given by Coan (1983).

northern Peru were identified to species level (Fig. 2, Table 1). However, only $20 \%$ of the specimens showed a perfect match with the morphotype expected from the species' description, while $80 \%$ of the specimens conflicted in at least one character by possessing a character state expected for the other species. Final assignment to species level was carried out by using the predominant number of morphological characteristics (Coan, 1983). The percentage of individuals exhibiting mismatches for each morphological character is presented in Table 3.

The northern Chilean population (Fig. 1, Table 1, Station 1) was composed only of clams identified as Donax obesulus. The central Peruvian beaches from Chincha to Chimbote (Fig. 1, Table 1, Stations 2-6) yielded predominantly Donax marincovichi morphotypes. In contrast, the population further north (Fig. 1, Table 1, Station 7) consisted exclusively of the $D$. obesulus morphotype, followed by Station 8 (Fig. 1, Table 1), which was inhabited by both morphotypes. The northernmost populations of Sechura and Tumbes (Fig. 1, Table 1, Stations 9 and 10) were composed of nominal D. obesulus morphotypes.

Among all the morphological characters used for identification in this study, only 'punctation' appeared to be reliable. As described by Coan (1983), it was predominant and/or prevalent on the $D$. obesulus morphotype, but never present on D. marincovichi. The most ambiguous identification features (Table 3) were 'colour' and 'distance from the posterior lateral to the cardinals' (respective mismatches of $46 \%$ and $38 \%$ ), followed by 'location of the periostracum' $(29 \%)$ and 'size of the anterior cardinal tooth' $(18 \%)$. The characters 'dorsal margin produced or not produced above posterior lateral' and ' $\mathrm{W} / \mathrm{H}$ ratio' conflicted in $12 \%$ of the cases. The characters 'surface' and 'shape of the beak' revealed $9 \%$ and $7 \%$ of mismatch, respectively (Table 3). Within the nine applied characters quantified by Coan (1983) the morphotype D. marincovichi $(n=56)$ possessed 133 mismatches, while morphotype D. obesulus $(n=53)$ revealed 58 mismatches (Table 3$)$.

$\mathrm{W} / \mathrm{H}$, as well as the $\mathrm{H} / \mathrm{L}$ ratio between all specimens, were tested and revealed significant differences $(P<0.001)$. Further comparisons between stations were made (Table 4 ), indicating that in terms of $\mathrm{W} / \mathrm{H}$ and $\mathrm{H} / \mathrm{L}$ ratios, stations from northern Chile and northern Peru (Fig. 1, Table 1, Stations 1, 7, 9 and 10), all dominated by $D$. obesulus, differed significantly from 
Table 4. Pairwise comparison of different sampling sites (Table 1) by Dunn test applied to identify differences in $\mathrm{W} / \mathrm{H}$ and $\mathrm{H} / \mathrm{L}$ between single stations.

\begin{tabular}{lll}
\hline & $\mathrm{W} / \mathrm{H}$ & $\mathrm{H} / \mathrm{L}$ \\
\hline 1 vs 2 & $0.000^{*}$ & $0.003^{*}$ \\
1 vs 3 & $0.000^{*}$ & $0.000^{*}$ \\
1 vs 4 & $0.002^{*}$ & $0.018^{*}$ \\
1 vs 6 & $0.003^{*}$ & $0.020^{*}$ \\
2 vs 7 & $0.021^{*}$ & $0.037^{*}$ \\
2 vs 8 & 0.151 & $0.025^{*}$ \\
2 vs 9 & $0.000^{*}$ & $0.042^{*}$ \\
2 vs 10 & $0.000^{*}$ & $0.000^{*}$ \\
3 vs 7 & 1.000 & $0.008^{*}$ \\
3 vs 8 & 1.000 & $0.005^{*}$ \\
3 vs 9 & $0.000^{*}$ & $0.009^{*}$ \\
3 vs 10 & $0.001^{*}$ & $0.000^{*}$ \\
4 vs 9 & $0.001^{*}$ & 0.208 \\
4 vs 10 & $0.013^{*}$ & $0.000^{*}$ \\
5 vs 10 & 0.458 & $0.000^{*}$ \\
6 vs 9 & $0.001^{*}$ & 0.211 \\
6 vs 10 & $0.018^{*}$ & $0.000^{*}$ \\
8 vs 9 & $0.044^{*}$ & 1.000 \\
\hline
\end{tabular}

Asterisks indicate significant differences $(P<0.05)$.

central Peruvian stations (Fig. 1, Table 1, Stations 2-6 and 8), which are dominated by $D$. marincovichi. Specimens of the former stations are more wedge shaped (shorter and thicker) indicating a compacter shape than clams from the other sites (Fig. 3).

However, in addition to individuals displaying all morphological characters of one species and thus easily identified, individuals from all stations (except station 10) showed a number of transitional character states thus making unequivocal identification difficult or impossible (Fig. 3). Recent results increased the maximum value of the $\mathrm{H} / \mathrm{L}$ ratio (Coan, 1983) (Table 2) for D. marincovichi to $0.62-0.73$ and for $D$. obesulus to $0.66-0.85$, respectively. Further sampling at Jahuay beach (Fig. 1, Table 1, Station 3) revealed that $D$. marincovichi reaches a maximum length up to $35 \mathrm{~mm}$ instead of $32 \mathrm{~mm}$ as reported by Coan (1983).

\section{Sperm morphology}

TEM observations of sperm structure of the two species D. marincovichi and D. obesulus (Coan, 1983) revealed that both demonstrate a typical primitive aquasperm type, containing an acrosome, nucleus, a short midpiece and a ring of mitochondria surrounding the flagellum (Fig. 4A). The pearshaped acrosome settles in a nuclear fossa (Fig. 4A, B). A transverse section of the acrosome is provided in Figure 4C. It illustrates that the acrosome is differentiated into two regions with different electron densities. The surrounding outer crescent-shaped basal ring is electron dense and represents c. $50 \%$ of the total area of the acrosome. It is covered by an outer acrosomal membrane. The anterior, central and posterior region is electron lucent containing the axial rod in the centre. The electron-lucent part of the acrosome apex is arrow-shaped (Fig. 4B). The sperm nucleus capturing approximately one-third of the total size of the sperm is associated with the acrosome (Fig. 4D). The flagellum shows the structure typical of molluscs: the axoneme within the flagellum consists of a central pair of microtubules encircled by nine doublets $(9+2$ type). Its termination is surrounded by four mitochondria (Fig. 4E). Mean values of length and diameter of the acrosome, nucleus and midpiece are given in Table 5 .

\section{Genetic analyses}

DNA of good quality was extracted from specimens whose shells were cracked open immediately before preservation, presumably because diffusion of ethanol into tissue depends mainly on the permeability of the surface texture of the organism (Held, 2000). In contrast, DNA of individuals preserved intact showed greater degradation and lower yields. DNA extracted from the middle piece of the foot was on average less in quantity and lower in quality, i.e. more fragmented. Consequently, all tissues used for DNA extraction were obtained from the anterior apex of the foot of previously sectioned individuals.

The alignment of the COI gene sequences yielded a 567-bp alignment. Analyses of uncorrected $P$-distances and haplotype sharing in the statistical parsimony network revealed no consistent differences between D. marincovichi and D. obesulus (Figs 5, 6). Strong differences were recorded for D. marincovichi and D. obesulus and the two Donax outgroup species $(>15 \% P$ distance, Fig 5). The pairwise genetic difference in D. obesulus$D$. obesulus or D. marincovichi-D. marincovichi pairs was equal to within-species pairwise comparisons, i.e. D. marincovichi$D$. obesulus pairs and vice versa $(0-1.2 \%)$. In addition, no genetic differentiation was observed between geographically separated populations.

For details of analysed specimens $(n=61)$ and number of matches and mismatches of identification after Coan (1983) see Supplementary material.

\section{DISGUSSION}

The $\mathrm{W} / \mathrm{H}$ and $\mathrm{H} / \mathrm{L}$ ratios obtained during this study revealed significant differences between Donax marincovichi and D. obesulus among sampling areas (Table 4). However, following the key of Coan (1983) (Fig. 2 and Table 2) these as well as other distinguishing characteristics frequently revealed incongruence concerning identification of the two species. Of the identified specimens $80 \%$ displayed characters of both morphotypes (Table 3). In order to clarify the taxonomic status we applied genetic tools and observed the sperm morphology of both morphotypes.

The genetic analysis indicated that COI gene sequences are useful for species discrimination within the genus Donax. The observed divergence levels $(0-1.2 \%)$ of both morphotypes pooled (Fig. 5) are typical of intraspecific levels (Held, 2000; Hebert et al., 2003; Cardenas, Castilla \& Viard, 2009). No consistent spatial structure was found in the distribution of genetic variance among geographically separated populations, suggesting extensive and ongoing gene flow between geographically separated populations and also between nominal $D$. obesulus and D. marincovichi. The same molecular marker system was highly informative when distinguishing the two Donax species included in the outgroup $(D$. asper and D. hanleyanus).

In addition, the examination of sperm morphology showed that sperm of both morphotypes were of a similar aqua sperm type (Fig. 4), which is typical of most members of the family Veneroidea (Healy, 1995). This sperm type is characterized by a conical acrosome, a short nucleus, a midpiece consisting of a ring of round mitochondria surrounding the centrioles and a single simple flagellum with a 9+2 axoneme (Healy, 1995, 2000). Comparison of the main components of the respective sperm revealed no differences in morphology. The electron 

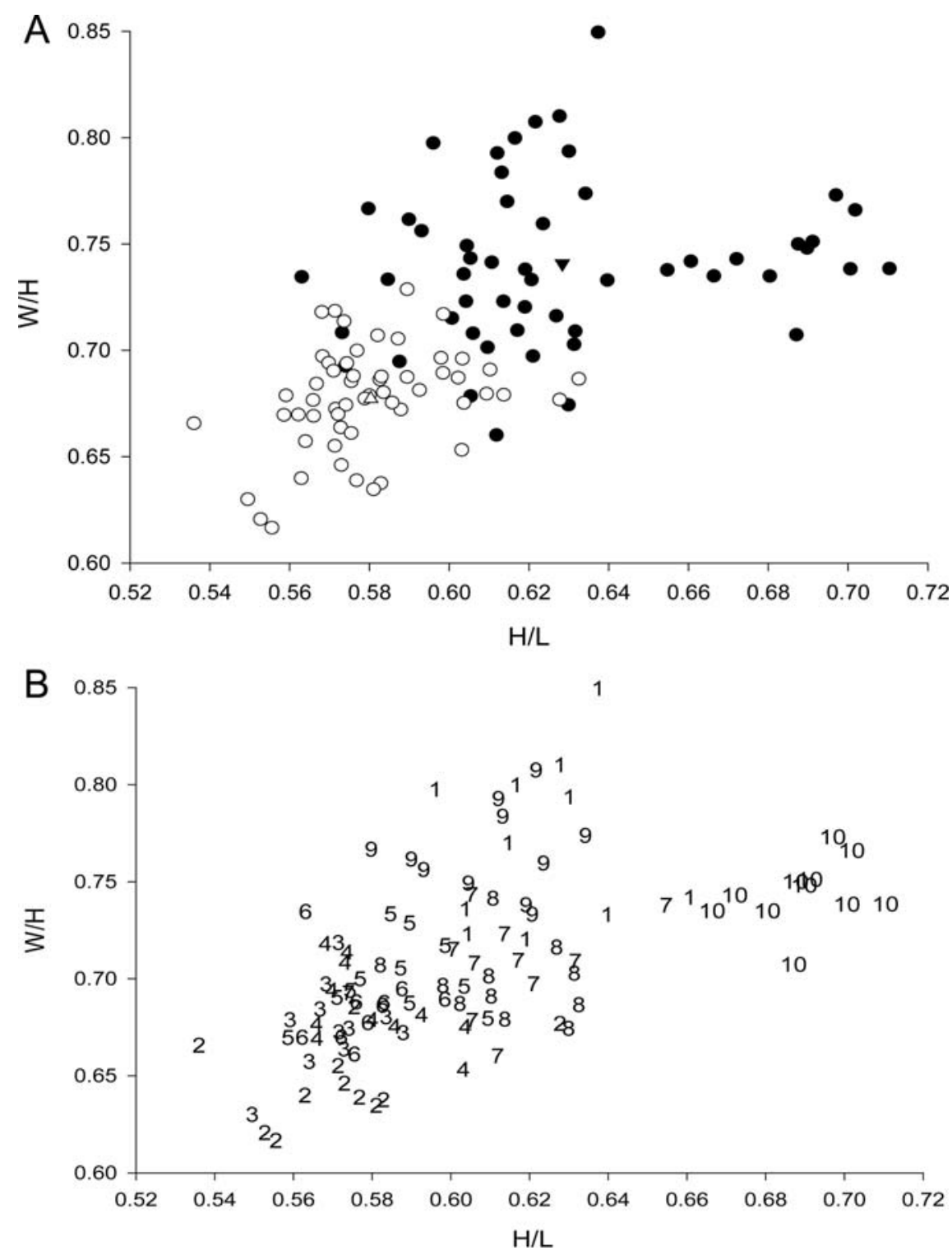

Figure 3. A. Shell shape variability of Donax marincovichi (open circles; mean: open triangle) and Donax obesulus (solid circles; mean: solid triangle) from stations along the Pacific coast of northern Chile and Peru. Width/height $(\mathrm{W} / \mathrm{H})$ ratios are plotted vs height/length $(\mathrm{H} / \mathrm{L})$. B. Shell shape variability of Donax marincovichi and Donax obesulus from Stations 1 to 10.

lucent part of the acrosome apex has an arrow-shaped point (Fig. 4B), which appears to be characteristic. A review of sperm of Donacidae (van der Horst et al., 1986; Hodgson, Bernard \& van der Horst, 1990; Sousa \& Oliveira, 1994; Healy, 1995; Matos et al., 1995; D. hanleyanus, M. Herrmann, unpublished) showed that the present sperm type differs in shape and size from those previously reported (Fig. 4, Table 5).

Neither significant mitochondrial genetic differentiation within or among populations, nor differences in sperm ultrastructure, separate the two morphotypes defined by Coan (1983) as distinct species. Therefore we propose that the differences between the morphotypes might be primarily the result of phenotypic plasticity caused by different local environments. We suggest that $D$. marincovichi and $D$. obesulus are better characterized as two different ecomorphs (sensu Nelson et al., 1993 ) of the species D. obesulus.

Within the study area geographically separated populations spanned approximately $1900 \mathrm{~km}$ (linear distance) from the southernmost station (Chinchorro Beach in Tarapacá, Chile) to the northernmost station (Sechura Bay in Tumbes, Peru). Meroplanktic larval development of Donax species takes about three to four weeks, depending on environmental conditions (food availability and temperature), and can be delayed under unfavourable conditions (Chanley, 1969; Helm, Bourne \& Lovatelli, 2004). The Peruvian Coastal Current (Fig. 1) transports water masses at speeds of up to $15 \mathrm{~cm} \mathrm{~s}^{-1}$, which is equivalent to approximately $400 \mathrm{~km}$ per month (Tarazona \& Arntz, 2000), implying that the analysed sub-populations may be interconnected via stepping-stone larval exchange within a modest number of generations. Similar long-distance interpopulational genetic connectivity has been recorded for D. serra populations from the Benguela Current Upwelling System (Laudien et al., 2003) and for D. deltoides populations connected by the East Australian Current (Murray-Jones \& Ayre, 1997).

Our results concur with numerous publications demonstrating that shell shape of Donacidae may vary greatly and that it is unreliable as a taxonomic feature (Olsson, 1961; Keen, 1971; Coan, 1983; Guzmán et al., 1998). This family is well known to 

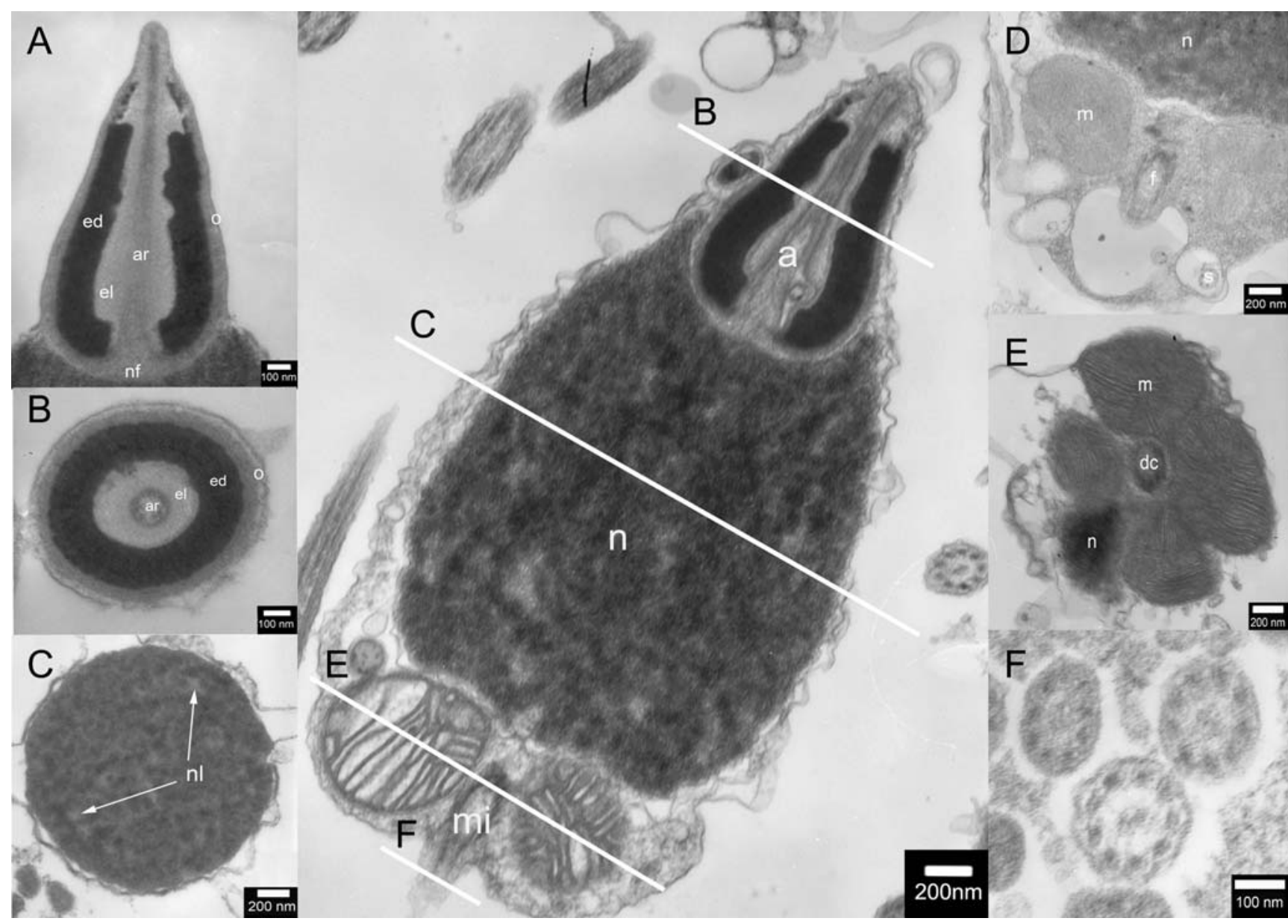

Figure 4. Overview in mid-longitudinal section through sperm type shared by Donax obesulus and Donax marincovichi, showing level of transverse sections $(20,000 \times)$. A. Detail, mid-longitudinal section of acrosome $(50,000 \times)$. B. Transverse section of acrosome $(60,000 \times)$. C. Transverse section of nucleus with brighter spots of nuclear lacunae $(20,000 \times)$. D. Detail, longitudinal section of satellite $(30,000 \times)$. E. Transverse section of four mitochondria, part of the nucleus and distal centriole $(30,000 \times)$. F. Transverse section of flagellum showing $9+2$ axoneme $(80,000 \times)$. Abbreviations: a, acrosome; ar, axial rod; dc, distal centriole; ed, electron-dense basal ring; el, electron-lucent region; f, flagellum; m, mitochondrion; mi, midpiece; n, nucleus; nf, nuclear fossa; nl, nuclear lacunae; o, outer plasma membrane; s, satellite.

Table 5. Comparison of sperm ultrastructure of Donax species: mean $( \pm \mathrm{SD})$ measurements (length and diameter) of acrosome, nucleus and midpiece.

\begin{tabular}{lllll}
\hline Species $(n)$ & Acrosome $(\mu \mathrm{m})$ & Nucleus $(\mu \mathrm{m})$ & Midpiece $(\mu \mathrm{m})$ & Author \\
\hline Donax sp. (39) & $1.38 \times 0.83( \pm 0.17 / \pm 0.06)$ & $2.11 \times 1.83( \pm 0.19 / \pm 0.20)$ & $0.68 \times 1.54( \pm 0.16 / \pm 0.29)$ & This study \\
Donax deltoides (5) & $1.18 \times 0.88$ & $0.67 \times 0.75$ & $0.6 \times 1.75$ & Healy $(1995)$ \\
Donax serra (20) & $0.9 \times 1.0$ & $1.33 \times 1.5$ & No data & Hodgson $(1990)$ \\
Donax sordidus (20) & $1.0 \times 0.8$ & $1.5 \times 1.4$ & No data & Hodgson $(1990)$ \\
Donax madagascariensis (20) & $1.07 \times 0.98$ & $1.56 \times 1.4$ & No data & Hodgson (1990) \\
\hline
\end{tabular}

span a wide spectrum of shell colour, pattern and shape. High heterogeneity has been documented for $D$. variabilis populations over short linear distances; at six stations covering $114 \mathrm{~km}$ of total distance, each population presented a unique combination in shell length and morph frequencies (Adamkewicz, 1989). Extreme diversity of shell characters and the absence of clear diagnostic features for Donacidae have also been reported in other studies (Wade, 1967a, b; Adamkewicz, 1989; Donn, 1990; Adamkewicz \& Harasewych, 1994; McLachlan et al., 1995; Laudien et al., 2003), suggesting that variation in size, colour, shape and sculpture of the shells may be due to phenotypic plasticity rather than an expression of genetic differentiation between the populations. McLachlan et al. (1995) studied the influence of beach morphodynamics on shell shape. Reflective beaches favour smaller, uniform and more wedge-shaped shells, while dissipative (Dean's parameter 5-10; for details see Defeo \& McLachlan, 2005) beaches instead favour larger valves with a broader spectrum of shapes. This was also documented for $D$. serra inhabiting reflective (Dean's parameter 0-2; Defeo \& McLachlan, 2005) vs intermediate (Dean's parameter 2-5) to dissipative beaches (Laudien et al., 2003). Donn (1990) stressed the influence of locality and population density and documented that a highintertidal population of $D$. serra at a higher density had thicker 


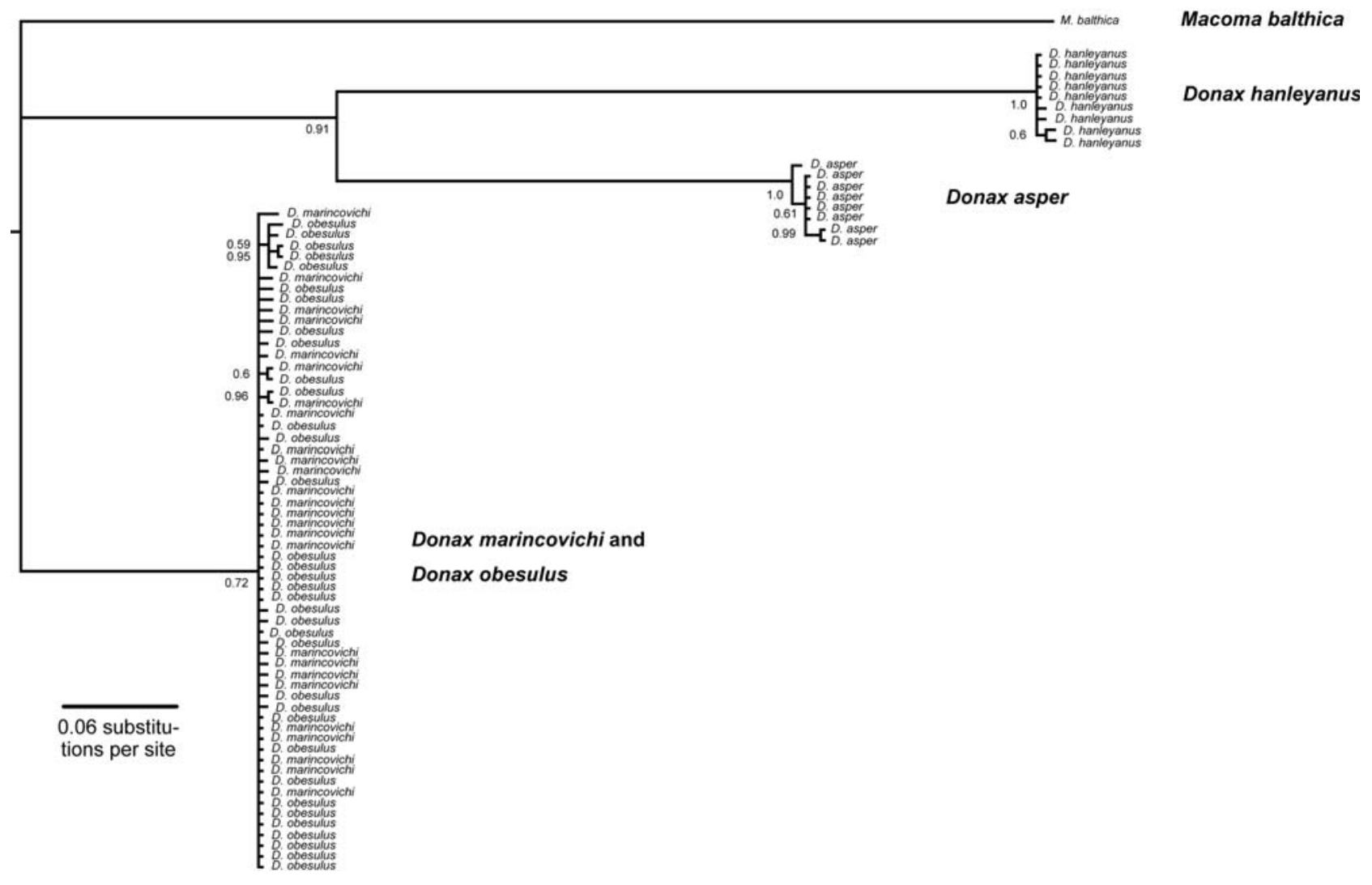

Figure 5. Majority rule $(>50 \%)$ consensus tree obtained from Bayesian analysis of the mitochondrial COI gene sequence data for Donax marincovichi, Donax obesulus and the outgroups Donax asper, Donax hanleyanus and Macoma balthica. Numbers below branches are posterior probability values.

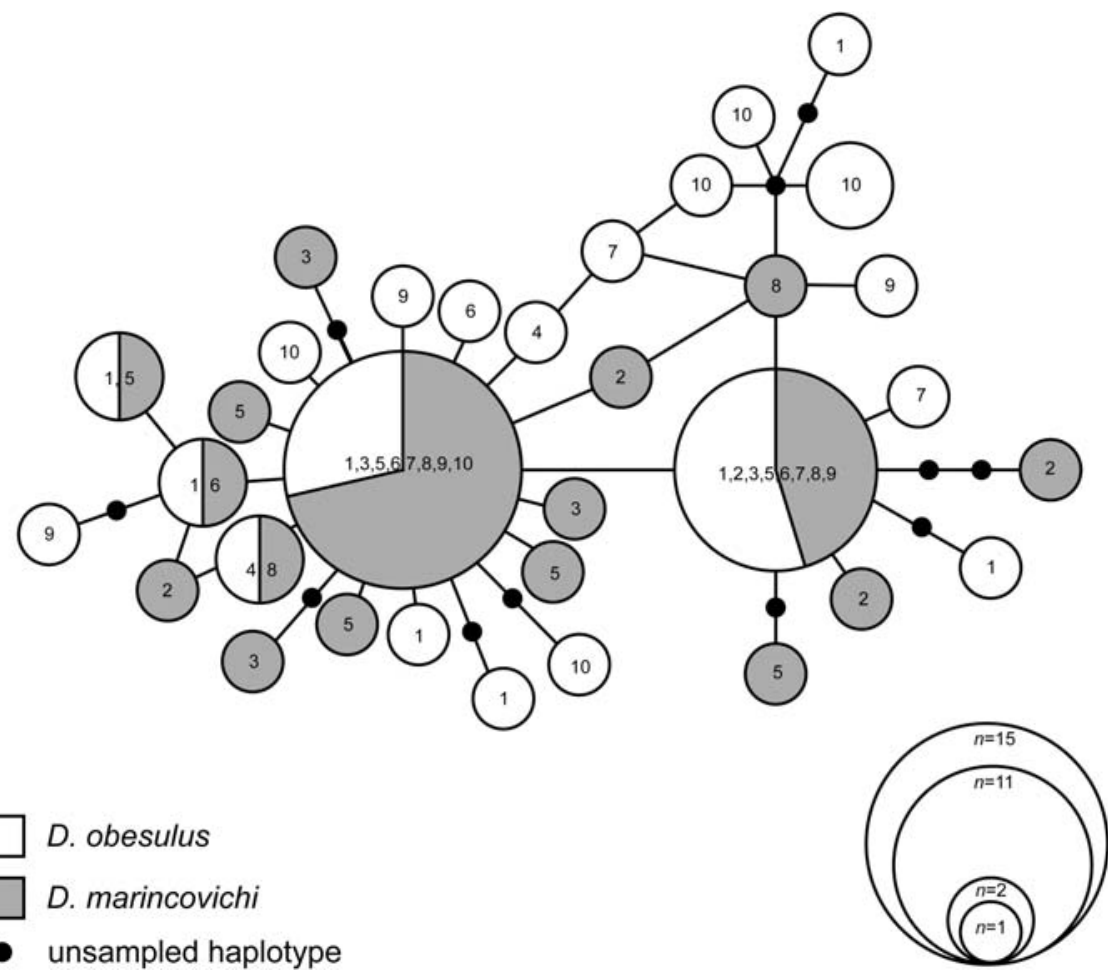

Figure 6. Statistical parsimony network (95\% connection limit) for the putative Donax marincovichi and Donax obesulus specimens sampled at station $1-10$. The diameter corresponds to the number of specimens found with a specific haplotype. The number(s) within each haplotype refer(s) to the station(s) at which the haplotype was found. 
and heavier shells, whereas low-intertidal or subtidal populations possessed flatter, more rounded shells. Considering the observed specimens, it can be suggested that the D. marincovichi morphotype may be more adapted to intermediate beaches because it has a flatter and less wedge-shaped form (Fig. 3), whereas the $D$. obesulus morphotype from northern Chile and Peru may be more adapted to reflective beaches, because it is shorter and more wedge-shaped (Fig. 3) (cf. McLachlan et al., 1995).

The diversity of synonyms of Donacidae reflects taxonomical confusion that is mainly due to the use of unreliable shell characteristics for species determination. Future research should include faster-evolving nuclear markers (e.g. AFLP, microsatellites) that could extend our findings based on mitochondrial sequences, and resolve more recent evolutionary events and at a finer geographic resolution than the present study (Held \& Leese, 2007).

In conclusion, as a consequence of environmentally driven phenotypic plasticity, analysis of shell morphology may be unsuitable for the delimitation of Donax species. Phenotypic plasticity in shape, dimensions, sculpture and colour can be considered adaptive for species living in environments that are physically and biologically dynamic, where it can give rise to distinctive ecomorphs.

\section{SUPPLEMENTARY MATERIAL}

Supplementary material is available at fournal of Molluscan Studies online.

\section{ACKNOWLEDGEMENTS}

This study is dedicated to Mario Javier Villegas Ortiz. It represents part of the first author's doctoral thesis and was partly supported by the University of Bremen. For essential help during sampling we are grateful to Jaime Mendo, Marc Taylor and Matthias Wolff, the working group of Juan Tarazona, particularly Giovanna Sotil, Elmer Ramos, Percy Gallegos, Giannina Passuni, Tunqui Palomino and to Americo Robles. For taxonomic advice during this study we are very thankful to Carlos Paredes. We are also grateful to John Healy, Natalio de Vincenzo, Susana Beatriz Jurado, Marko Herrmann, José Riascos, Carmen Yamashiro, Anegret Müller, Uwe John and Ana Sofía Salazar Morales for their support during this study. An early manuscript draft was improved by the thoughtful comments of Eugene Coan and two anonymous reviewers. This study was conducted as part of the EU-funded FP6-INCO-STREP project, Climate Variability and El Niño-Southern Oscillation: Implications for Natural Coastal Resources and Management (CENSOR-CT-2004-511071) and is CENSOR publication No. 384.

\section{REFERENCES}

ADAMKEWICZ, S.L. 1989. Differences in the frequencies of several characters in the clam Donax variabilis around Cape Hatteras, North Carolina. Veliger, 32: 21-28.

ADAMKEWICZ, S.L. \& HARASEWYCH, M.G. 1994. Use of random amplified polymorphic DNA (RAPD) markers to asses relationships among beach clams of the genus Donax. The Nautilus, 2: $51-60$.

ANSELL, A.D. 1983. The biology of the genus Donax. In: Developments in hydrobiology. Vol. 19: Sandy Beaches as Ecosystems (A. McLachlan, T. Erasmus \& W.E. Junk eds), pp. 607-635. W. Junk, The Hague, The Netherlands.

BONSDORFF, E. \& NELSON, W.G. 1992. The ecology of coquina clams Donax variabilis Say, 1822, and Donax parvula Philippi, 1849, on the east coast of Florida. Veliger, 35: 358-365.
CARDENAS, L., CASTILLA, J.G. \& VIARD, F. 2009. A phylogeographical analysis across three biogeographical provinces of the south-eastern Pacific: the case of the marine gastropod Concholepas concholepas. Fournal of Biogeography 36: 969-981.

CHANLEY, P. 1969. Donax fossor: a summer range extension of Donax variabilis. Nautilus, 83: 1-14.

CLEMENT, M., POSADA, D. \& CRANDALL, K.A. 2000. TCS: a computer program to estimate gene genealogy. Molecular Ecology 9: $1657-1659$.

COAN, E. 1983. The Eastern Pacific Donacidae. Veliger, 25: 273-298.

COAN, E.V., SCOTT, P. \& BERNARD, F.R. 2000. Bivalve seashells of western North America: marine bivalve mollusks from Arctic Alaska to Baja California. Museum of Natural History Monographs, Santa Barbara: $764 \mathrm{p}$.

COGHLAN, B. \& GOSLING, E. 2007. Genetic structure of hybrid mussel populations in the west of Ireland: two hypotheses revisited. Marine Biology, 150: 841-852.

DEFEO, O. \& MCLACHLAN, A. 2005. Patterns, processes and regulatory mechanisms in sandy beach macrofauna: a multi-scale analysis. Marine Ecology Progress Series, 295: 1-20.

DONN, T.E.J. 1990. Morphometrics of Donax serra Röding (Bivalvia: Donacidae) populations with contrasting zonation patterns. Fournal of Coastal Research, 6: 893-901.

EDGAR, R. 2004. Muscle: multiple sequence alignment with high accuracy and high throughput. Nucleic Acids Research, 32: $1792-1797$.

FOLMER, O., BLACK, M., HOEH, W., LUTZ, R. \& VRIJENHOEK, R. 1994. DNA primers for amplification of mitochondrial cytochrome $\mathrm{c}$ oxidase subunit I from diverse metazoan invertebrates. Molecular Marine Biology and Biotechnologie, 3: $294-299$.

GALTSOFF, P.S. \& GALLARDO, C.S. 1960. Ultrastructure of the spermatozoon of the oyster Crassotrea virginica. Fournal of Ultrastructural Research, 3: 241-253.

GIMÉNEZ, J., HEALY, J.M., HERMIDA, G.N., NOSTRO, F.L. \& PENCHASZÁDEH, P.E. 2008. Ultrastructure and potential taxonomic importance of euspermatozoa and paraspermatozoa in the volutid gastropods Zidona dufresnei and Provocator mirabilis (Caenogastropoda, Mollusca). Zoomorphology, 127: 161-173.

GUZMÁN, N., SAÁ, S. \& ORTLIEB, L. 1998. Catálogo descriptivo de los moluscos litorales (Gastropoda y Pelecypoda) de la zona de Antofagasta $23^{\circ} \mathrm{S}$ (Chile). Estudios Oceanológicos, Universidad de Antofagasta, 17: 17-86.

HEALY, J.M. 1995. Comparative spermatozoal ultrastructure and its taxonomic and phylogenetic significance in the bivalve order Veneroida. In: Advances in spermatozoal phylogeny and taxonomy (B.G.M. Jamieson, J. Ausio \& J.-L. Justine eds), pp. 155-166. Mémoires du Muséum National D' Histoire Naturelle, Paris.

HEALY, J.M., KEYS, J.L. \& DADDOW, L.Y.M. 2000. Comparative sperm ultrastructure in pteriomorphian bivalves with special reference to phylogenetic and taxonomic implications. In: The evolutionary biology of the Bivalvia (E.M. Harper, J.D. Taylor \& J.A. Crame eds), pp. 169-190. Geological Society Special Publication.

HEBERT, P.D.N., RATNASINGHAM, S. \& DEWAARD, J.R. 2003. Barcoding animal life: cytochrome c oxidase subunit 1 divergences among closely related species. Proceedings of the Royal Society of London, Series B: Biological Sciences, 270: 96-99.

HELD, C. 2000. Phylogeny and biogeography of serolid isopods (Crustacea, Isopoda, Serolidae) and the use of ribosomal expansion segments in molecular systematics. Molecular Phylogenetics and Evolution, 15: 165-178.

HELD, C. \& LEESE, F. 2007. The utility of fast evolving molecular markers for studying speciation in the Antarctic benthos. Polar Biology, 30: 513-521.

HELD, C. \& WÄGELE, J.W. 2005. Cryptic speciation in the giant Antarctic Isopod Glyptonotus antarcticus (Isopoda: Valvifera: Chaetiliidae). Scientia Marina, 69: 175-181.

HELM, M.M., BOURNE, N. \& LOVATELLI, A. 2004. Hatchery culture of bivalves. A practical manual. FAO Fisheries Technical Paper, 471: 177. 
HODGSON, A.N., BERNARD, R.T.F. \& VAN DER HORST, G. 1990. Comparative spermatology of three species of Donax (Bivalvia) from South Africa. Fournal of Molluscan Studies, 56: 257-265.

HUARAZ, F. \& ISHIYAMA, V. 1980. Madurez sexual de la 'concha mariposa' (Donax peruvianus) de la playa de Jahuay, Ica, Perú. Revista de Ciencias U.N.M.S.M., 72: 47-56.

HUELSENBECK, J. \& RONQUIST, F. 2001. MrBayes: Bayesian inference of phylogenetic trees. Bioinformatics, 17: 754-755

JAERNEGREN, J., SCHANDER, C., SNELI, J.-A., ROENNINGEN, V. \& YOUNG, C.M. 2007. Four genes, morphology and ecology: distinguishing a new species of Acesta (Mollusca; Bivalvia) from the Gulf of Mexico. Marine Biology, 152: $43-55$.

KEEN, A.M. 1971. Sea shells of tropical West America. Edn 2. Stanford University Press, Standford, California.

KIMURA, M. \& WEISS, G.H. 1964. The stepping stone model of population structure and the decrease of genetic correlation with distance. Genetics, 49: 561-576.

KOEHN, R.K., HALL, J.G., INNES, D.J. \& ZERA, A.J. 1984. Genetic differentiation of Mytilus edulis in eastern North America. Marine Biology, 79: 117-126.

LAUDIEN, J., FLINT, N.S. \& BANK, F.H.V.D. 2003. Genetic and morphological variation in four populations of the surf clam Donax serra (Röding) from southern African sandy beaches. Biochemical Systematics and Ecology, 31: 751-772.

LEVINTON, J.S. \& SUCHANEK, T.H. 1978. Geographic variation, niche breadth and genetic differentiation at different geographic scales in the mussels Mytilus californianus and M. edulis. Marine Biology, 49: 363-375.

LOESCH, H.C. 1957. Studies of the ecology of two species of Donax on Mustang Island, Texas. Publications of the Institute of Marine Science, 4: $201-227$.

MATOS, E., MATOS, P., CORRAL, L. \& AZEVEDO, C. 1995. Estudo ultraestrutural da espermatogenese de Donax striatus Linnaeus (Mollusca, Bivalvia) do litoral norte do Brasil. Revista Brasileira de Zoologia, 12: 221-227.

MCLACHLAN, A., JARAMILLO, E., DEFEO, O., DUGAN, J.E., RUYCK, A.D. \& COETZEE, P. 1995. Adaptions of bivalves to different beach types. Fournal of Experimental Marine Biology and Ecology, 187: 147-160.

MORRISON, J.P.E. 1971. Western Atlantic Donax. Proceedings of the Biological Society of Washington, 83: 545-568.

MURRAY-JONES, S.E. \& AYRE, D.J. 1997. High levels of gene flow in the surf bivalve Donax deltoides (Bivalvia: Donacidae) on the east coast of Australia. Marine Biology, 128: 83-89.

NARCHI, W. 1983. Donax hanleyanus Philippi, 1847, proposed conservation and proposed suppression of Donax hilairea Guerin, 1832 (Mollusca, Bivalvia). Z.N. (S.) 2152. Bulletin of Zoological Nomenclature, 40: 188-189.

NELSON, W.G., BONSDORFF, E. \& ADAMKEWICZ, L. 1993. Ecological, morphological, and genetic differences between the sympatric bivalves Donax variabilis Say, 1822, and Donax parvula Philippi, 1849. Veliger, 36: 317-322.

NYLANDER, J. 2004. MrModeltest2.2. Computer software distributed by the University of Uppsala.

OLSSON, A.A. 1961. Mollusks of the tropical eastern Pacific, Panamic Pacific Pelecypoda. Paleontological Research Institute, Ithaca.
PAL, S.G. 1996. Some observations on the testes of Donax lubrica (Bivalvia: Donacidae). Malacological Review, 6: 55-62.

PALUMBI, S.R., MARTIN, A. \& ROMANO, S. 1991. The simple fool's guide to PCR, Version 2.0. University of Hawaii, Honolulu.

PAREDES, C. \& CARDOSO, F. 2001. El género Donax en la costa peruana (Bivalvia: Tellinoidea). Revista Peruana de Biología, 8: 1-13.

REEVE, L.A. 1854. Monograph of the genus Donax. In: Conchologia iconica (L.A. Reeve ed.). London.

REY, R. 2006. Prohíben la extracción, recepción, transporte, procesamiento y comercialización del recurso marucha en tallas inferiores a 22 milímetros de longitud valvar: Resolución Ministerial № 298-2006-Produce: 2. Perú: Imarpe, Informe $\mathrm{N}^{\circ}$ 300-2006PRODUCE/DGEPP-Dch.

REY, R. 2007. Prohíben la extracción, recepción, transporte, procesamiento y comercialización del recurso marucha en tallas inferiores a 22 milímetros de longitud valvar: Resolución Ministerial $\mathcal{N}^{\circ}$ 445-2007-Produce: 2. Perú: Imarpe, Informe $\mathrm{N}^{\circ}$ 544-2007PRODUCE/DGEPP-Dch.

REY, R. 2008. Prohíben actividades de extracción, procesamiento, transporte y comercialización del recurso marucha o palabritas en el litoral y ámbito del departamento de Lambayeque: Resolución Ministerial № 607-2008-Produce: 2. Perú: Imarpe, Informe $\mathrm{N}^{\circ}$ 452-2008-PRODUCE/DGEPP-Dch.

RIASCOS, J.M. 2006. Effects of El Niño-Southern Oscillation on the population dynamics of the tropical bivalve Donax dentifer from Málaga bay, Colombian Pacific. Marine Biology, 148: $1283-1293$.

SOARES, A.G., SCAPINI, F., BROWN, A.C. \& MCLACHLAN, A. 1999. Phenotypic plasticity, genetic similarity and evolutionary inertia in changing environments. Journal of Molluscan Studies, 65: 136-139.

SOTO, R. 1985. Efectos del fenómeno El Niño 1982-83 en ecosistemas de la 1 Región. Investigación Pesquera (Chile), 32: 199-206.

SOUSA, M. \& OLIVEIRA, E. 1994. Ultrastructural and cytochemical study of spermatogenesis in Donax trunculus (Mollusca, Bivalvia). Fournal of Submicroscopic Cytology and Pathology, 26: 305-311.

TARAZONA, J. \& ARNTZ, W. 2000. The Peruvian coastal upwelling system. Ecological Studies, 144: 229-244.

UTTER, F.M. 1991. Biochemical genetics and fisheries managment: a historical perspective. Fournal of Fish Biology, 39: 1-20.

VAN DER HORST, G., HODGSON, A.N., BERNARD, R., SALIE, W. \& MAASDORP, L.J.W. 1986. Sperm ultrastructure in two Donax (Bivalvia) species. Proceedings of the Electron Microscopial Society of South Africa, 16: 69-70.

WADE, B.A. 1967a. On the taxonomy, morphology, and ecology of the beach clam, Donax striatus. Bulletin of Marine Science, 17: $723-740$.

WADE, B.A. 1967b. Studies on the biology of the West Indian beach clam, Donax denticulatus L. I. Ecology. Bulletin of Marine Science, 17: $149-174$.

WITT, J.D.S., THRELOFF, D.L. \& HEBERT, P.D.N. 2006. DNA barcoding reveals extraordinary cryptic diversity in an amphipod genus: implications for desert spring conservation. Molecular Ecology, 15: $3073-3082$.

ZAR, J.H. 1999. Biostatistical analysis. Edn 4. Prentice-Hall Inc., Upper Saddle River. 